\title{
Harnessing the Internet for pension scheme communication: Legal considerations for pensions intranet and websites \\ Received: 19th February, 2001
}

\section{Belinda Benney}

is the head of Field Fisher Waterhouse's pensions practice. She was educated in Ipswich, Suffolk and read law at Bristol University, obtaining an LL.B degree in 1978. She served articles in Bristol and, on qualification as a solicitor in 1981, joined a City firm to practise in private client matters (wills, trusts, probate and tax-planning). Belinda decided to specialise full-time in pensions law in 1986 and is a well-known speaker on the pensions lecture circuit. She was a member of the Association of Pension Lawyers Barber Committee throughout its life (1990-95) and is a member of the Institute of Chartered Accountants Pensions Sub-Committee. In April 2000, Belinda was appointed as a member of the Board of the Occupational Pensions Regulatory Authority (Opra). She is the author of 'A Guide to the Pensions Act 1995' (Butterworths, 1995) and the pensions chapter in Tolley's 'Administration of Estates' practitioners' manual published in 1997.

\begin{abstract}
This paper was presented at the IBC 'Harnessing the Internet for pension scheme communication' Conference on 16th February, 2001. It examines the implications for UK occupational pension schemes of communicating with scheme members electronically. The Disclosure Regulations and the Data Protection Act 1998 compliance requirements are considered. There is also some commentary on website copyright and the Electronic Communications Act 2000.
\end{abstract}

Keywords: virtual disclosure; e-mail benefit statements; websites; data protection

Belinda Benney Field Fisher Waterhouse, 35 Vine Street, London EC3N 2AA.

Tel: $+44(0) 2078614000$; Fax: +44 (0)20 7488 0084; www.ffwlaw.com

\section{Introduction}

This paper examines the legal considerations for pensions intranet sites. The information will also be relevant for pension schemes or employers which are setting up a pensions extranet site - ie, a secure site from a separate server to the company's intranet which is open to selected third parties. (Different considerations generally apply to pension providers seeking to use the Internet for selling pension products such as stakeholder pensions and these will not be covered).

These days, the Trust Deeds and Rules of pension schemes are not offered to members on joining a pension scheme. The important summary for the member of his or her rights and benefits under the pension scheme will be the booklet. If a company is offering automatic entry to its scheme or wishing to encourage take-up by members, giving them a booklet is a way of showing commitment to the scheme by the employer. Members are also likely to feel a greater sense of 'ownership' of the pension scheme. This is on the same basis that people prefer to have a building society passbook rather than a paperless savings account.

Annual benefit statements are also 
traditionally issued in paper form to scheme members. Is it really necessary to provide booklets and benefit statements in this way or is it now possible and/or more appropriate for these documents to be provided to staff through the company's intranet or e-mail system?

\section{The 'virtual booklet'}

Many companies aspire to the concept of the paperless office. In terms of pension schemes, this has been reflected in a wish to provide the members' booklet on the company's intranet site without issuing hard copies at all.

While the 'virtual booklet' is possible to achieve within certain legal constraints, it may not necessarily be totally desirable. In the wish to be at the cutting edge of e-commerce, the main purpose of the members' booklet can be overlooked in the interests of conforming with other aspects of a company's general human resources strategy. Before looking at delivery of the members' booklet, whether in hard paper copy or by electronic means, the pensions manager should think carefully about what the booklet is intended to achieve over and above the statutory disclosure requirements.

\section{Disclosure Regulations 1996}

The governing Regulations are the Occupational Pension Schemes (Disclosure of Information) Regulations 1996 (SI No. 1655) as amended. These provide that the trustees of an occupational pension scheme 'shall furnish in writing' various items of information to members of their pension scheme and to prospective members.

The Regulations divide disclosure obligations between those where information must be 'furnished in writing' and those where there is a simple duty to 'inform' or 'make available'. Traditionally, it has been assumed that the obligation to furnish information 'in writing' means that the information must be supplied in paper form to each individual recipient. This has been achieved by production of a members' booklet which is also used as a selling tool to promote the pension scheme concerned.

Provision of information to scheme members through e-mail or intranet is an acceptable interpretation of the Disclosure Regulations according to the Department for Social Security subject to certain protections outlined below.

\section{Record keeping}

Some form of paper trail will continue to be necessary as the members' booklet is a pension scheme document which may evidence important changes to the scheme benefit structure before they are formally introduced into the Trust Deed and Rules. In particular, in order to ensure that a full record is maintained of the terms of the booklet applicable to each category of staff, a hard copy of the electronic version should be printed off whenever a change is made and kept with the pension scheme trust documents.

In addition, no changes should be made to the booklet unless they have the prior authorisation of the trustees. This should be dealt with by means of a trustee resolution annexing a draft of the revised booklet or pages.

\section{Security}

The master booklet held on the company's intranet must be 'read only' and password protected to make sure that there are no inadvertent amendments unless they have been approved by a proper procedure through 
the trustees. The pensions manager should also be able to confirm exactly which members have been provided with a particular version of the booklet.

It is assumed here that the electronic version of the booklet will be generic and will not contain member-specific information, and that any special arrangements applying only to a small group of members (for example, senior executives) would be notified on an individual basis to those members by separate 'mini-booklet' or individual letter announcement.

Some of the larger corporate groups have a number of pension schemes available to different categories of staff as a result of historic acquisitions. Giving all staff full access to the pensions intranet site with details of the different schemes might lead to some dissatisfaction. Trustees must be prepared for queries from members of one scheme who perceive their benefits to be substantially less generous than those of members of other schemes within the group. Leaving a senior executive scheme off the intranet might be an option or restricting access to senior executives only.

\section{Access}

It is essential that all active members of the pension scheme have access to the intranet and e-mail system. Accordingly, part-timers, cleaners, post-room staff etc. who are members of the pension scheme must have reasonable daily access to a PC. Relevant training for staff who do not regularly use PCs may need to be considered or the provision of a 'pensions kiosk' in canteens or rest rooms.

It is also essential that all members of the scheme are aware of the location of the booklet on the company's intranet and have access to it. This second requirement could be met by giving each current active member a note in their payslip or by some similar means explaining the revised arrangements concerning the booklet. New staff can be informed of these arrangements as and when they join the company.

\section{Hard copies}

There may be some changes from time to time which have an impact on deferred or pensioner members. Those changes would obviously have to be notified to those categories of member on an individual basis, on paper.

It is unlikely that the printed-off version of the electronic booklet will look as smart as a bound and/or professionally printed booklet, particularly as it will normally be limited to black and white with little scope for good quality pictures and graphics. From a promotional viewpoint, therefore, the electronic booklet may lead members to undervalue the pension scheme benefits. This could be countered by individual counselling or group presentations for new joiners.

\section{The 'virtual benefit statement'}

\section{Disclosure by e-mail}

This section examines whether it would be legally permissible to issue benefit statements to members of an occupational pension scheme by encrypted e-mail instead of paper statements sent to each member individually.

The Dti consultation document 'Building Confidence in E-Commerce' issued in the context of the draft Electronic Communications Bill in 1999 expressed some doubt whether any legal requirement that a document should be in writing could be satisfied by producing the document electronically. 
We now have the Electronic

Communications Act 2000 which

confirms that the term 'in writing' may

be deemed to include satisfactory

electronic communications.

The DSS Pensions Policy Unit's view

is that a requirement for a

communication to be in writing only

suggests that individual disclosure is

needed and that e-mail would currently

meet the pensions disclosure

requirements. If the disclosure is made

by e-mail, however, the trustees of the

relevant pension scheme must be sure

that every person e-mailed did receive

the communication.

\section{Disclosure Regulations 1996 (again)}

The legal position here is different for money purchase and final salary pension schemes as they have different disclosure requirements.

A money purchase scheme is required under Regulation 5 (5) of the Disclosure Regulations to issue annual benefit statements to members. In contrast, a final salary scheme is not obliged to issue annual benefit statements except on member request, although many final salary schemes do so and this would be considered best practice. If some final salary scheme members did not receive an e-mailed annual benefit statement, this would not be a breach of the Disclosure Regulations, whereas it would be a breach for a money purchase scheme where the annual statements are mandatory, not voluntary. It would seem sensible, however, to treat both schemes in the same way for general administrative purposes.

\section{Personal access and security}

It is currently accepted that an annual benefit statement may be delivered to active members of a final salary or a money purchase pension scheme by encrypted e-mail provided each recipient has his or her own e-mail address and the ability to print off a hard copy for record purposes.

For this purpose, the test is whether all staff will have their own personal e-mail addresses. If they do, the only security risk would be if any members have shared access to a computer (where hard copy statements only might need to be sent to preserve confidentiality if staff can read each other's e-mails).

The other security matter would relate to trustee records of the benefit statements sent. The trustees of the smaller insured schemes often merely distribute the annual benefit statements provided by the insurer to members and do not keep hard copies of each benefit statement issued. Larger schemes tend to have a standard pro-forma benefit statement into which the individual figures are inserted from a master list which is then kept showing to whom the statements have been issued. Since members sometimes have queries about their benefit statements, it would be important for the trustees of the scheme to have a record themselves of what was sent which could be quickly accessed for checking purposes or in the event of a dispute.

\section{Verification of delivery}

The burden of proof of sending out the statements by e-mail is different from sending statements in the post (where there is an automatic presumption of safe delivery even if letters sometimes go astray) because the trustees have to show that members received the e-mail and were able to print it off.

It is therefore very important to use the 'return receipt' e-mail facility. The pensions manager would need to check the return receipts within, say, a ten-day 
period of sending out the statements. If any receipts showed that the e-mail had either not been delivered or opened, a hard copy benefit statement should be sent to those members in the normal way as back-up to prove safe delivery.

\section{Interactive software}

If a company decides to launch a pensions website, many will include a benefit modeller as well. This customised software enables members to access information on an interactive basis, obtaining quotes etc. where required.

The trustees of the pension scheme will need to ensure the accuracy of these interactive elements by rigorous checking before they 'go live' and regularly afterwards. This is because much pensions litigation and disputes have centred round mistakes on early retirement or AVC quotations.

Revenue Limits are extremely complex and may well have a significant distorting effect on these programmes. For example, it is vital that the earnings cap is featured if the company employs higher paid staff.

\section{Website copyright}

If a company has spent a considerable amount of time and money on developing its website, it is unlikely to want its competitors to be able to steal its ideas and save on their own development costs.

Where a website has been developed in-house, the company will own the copyright in the website as anything created by one of its employees was done in work time and is thus for the benefit of the employer.

But if the website was developed by an external third party for a fee, the copyright would normally belong to the consultant or design agency as author of the work. It is therefore very important when commissioning the work on the website for the employer to check that the intellectual property rights in the site will be assigned. Most standard terms and conditions provide for the copyright to remain with the design agency and this is frequently overlooked. Ownership of copyright should also be considered where the design agency or consultant may sub-contract the project to another party.

Another developing area to watch is more applicable to US websites. In the States, it is possible to take out a patent over a business method used in a website for doing business or the software. The party who purchases the patent can then seek to charge a licence fee from anyone else using that particular method or technology in their own website. It is therefore worth considering obtaining third party IPR indemnity cover or stressing in the project agreement that the developer is expected to do the due diligence as to whether aspects of the site could require a licence under someone else's patent.

\section{Data Protection Act 1998 ('DPA')}

\section{Need for consent from pension scheme members}

The DPA came into force on 1st March, 2000 although there is a transitional period up to 3rd October, 2001 for most purposes (with a longer period up to 2007 where manual data are concerned). It introduced a far more restrictive regime with respect to the protection and processing of personal data.

The DPA requires the fulfilment of certain pre-conditions before data can be obtained 'fairly and lawfully'. Two of the pre-conditions are particularly relevant for pension schemes: 
1 the data subject has given his/her consent to the processing. This will be appropriate for new members where the application form to join the scheme has appropriate wording covering data protection and the member gives specific written consent to the use of data by the pension scheme.

Some pension schemes have been advised to send notifications on behalf of the trustees and the sponsoring employer to existing scheme members on the basis that this will constitute implied member consent where it is felt impracticable to obtain the written consents of existing members. This is not really an effective solution as the Data Protection Commissioner has said that consent must involve an active communication between the parties. In some cases, consent could be implied, but this cannot be inferred from a failure to respond to a communication. Trustees would be better advised to rely on one of the other pre-conditions described below for existing scheme members.

2 processing is necessary in order to protect the legitimate interests of the data controller (ie, the trustees)

Correspondence between the Association of Pension Lawyers and the office of the Data Protection Commissioner indicates that member consent may not be necessary, as in most cases pension schemes will be able to rely on the pre-condition that processing is necessary for the legitimate interest of the trustees as data controllers. The Secretary of State can specify circumstances in which the pre-condition is or is not satisfied.

There is no sign of a specific exemption for pension schemes being granted in the future and the full extent of the scope of this pre-condition has not yet been tested.
It seems clear, however, that trustees could not administer the benefits of their pension scheme without holding the appropriate membership details such as salary, date of birth, family relationships, salary etc. and death benefit nomination forms. This pre-condition would therefore seem to cover the situation of existing members of pension schemes whose original application forms did not require specific consent to the use of personal data.

To summarise, there is no need to write to pension scheme members specifically with regard to their data protection rights as admission to membership of the scheme automatically satisfies pre-condition (2) above. It would be best practice, however, to obtain the individual consents of new members so that they understand the data protection implications of joining their scheme. This can most simply be included on the membership application form issued by the trustees as they are the 'data controllers' for the purposes of the scheme. The sponsoring employer will be holding data on its employees for wider purposes and should accordingly protect its own position in the employment contract or by separate notification or consent.

\section{Third parties}

When obtaining consents from new members, one also has to consider the status of data which they may give to the pension scheme trustees about other data subjects - such as a spouse, dependant or child for the purposes of survivor pensions or on a nomination form for payment of lump-sum death benefit under discretionary trust. A member cannot give consent on behalf of another person. 
It is, however, possible for the member to explain to another person (such as a spouse), the reasons for the member wanting to give data to the trustees about that person, obtain the consent of that person for disclosure and then pass on that consent to the trustees. This is obviously not as satisfactory as the trustees obtaining consent from the third party, but this would be impracticable in the real world. It is possible to include wording covering this type of disclosure in the membership application form. When tested to destruction, this analysis breaks down over disclosure of children's data and the trustees might have to rely ultimately on the general 'legitimate interest' exemption.

The DPA also places new obligations on data controllers in respect of data processed on their behalf by third parties (defined as 'data processors' under the Act). Some schemes have their pension administration dealt with in-house and frequently this will not be documented in the form of an administration agreement. Formal outsourcing arrangements by schemes with external third parties are normally documented by administration agreements, but not always where the outsourcing is long-standing. If there is no formal administration agreement in place between trustees and their administrator, the trustees should raise this issue as soon as possible and at the least set up a formal exchange of letters covering data protection security.

The trustees as data controllers must obtain sufficient guarantees from their administrator as the data processor in respect of their security measures and take reasonable steps to ensure that the administrator complies with those measures. This should take the form of a written agreement between the administrator and the trustees under which the administrator agrees to act only on the instructions of the trustees and comply with data security obligations equivalent to the trustees' own obligations under the DPA.

Most professional administrators will now have some standard wording to cover the new legislation and have in place appropriate internal technical and organisational data security measures but trustees should make their own enquiries and establish a formal agreement on this point.

\section{Damage limitation}

To avoid liability in contract, for negligence or for breach of data protection laws, trustees must take care in the design and establishment of their data processing and interactive software systems. This will involve use of anti-virus software and appropriate security systems such as firewalls. The seventh data protection principle in Schedule 1 of the DPA states that:

\footnotetext{
'Appropriate technical and organisational measures shall be taken against unauthorised or unlawful processing of personal data and against accidental loss or destruction of, or damage to, personal data.'
}

\section{Electronic Communications Act 2000}

The European Council and Parliament adopted the Electronic Signatures Directive in January 2000. Member states have until July 2001 to implement the Directive into national law. The Directive is intended to harmonise the legal acceptance of electronic signatures throughout the European Union as an equivalent to handwritten signatures to ensure that transactions can be performed without the risk of forgery and can be used as evidence in court.

The Electronic Communications Act 
2000 received the Royal Assent on 25th May, 2000. The key purpose of the Act is to implement the Electronic Signatures Directive into national law and to assist in the building of confidence in e-commerce and the underlying technology. It provides for:

- an approvals system for businesses and other organisations, including a registration scheme for certification authorities

— the legal recognition of electronic signatures. (The Act did not impose a blanket rule that electronic signatures will be automatically valid. This will be implemented over time by specific orders under the Act in different areas where the existing law requires paper documents or signatures)

- the removal of obstacles in other legislation to the use of electronic communication and storage in place of paper.

\section{Conclusion}

There is no doubt that the Internet revolution has arrived. Technology is changing fast and will bring huge changes to the way we all do business and live our lives. Pension schemes will not be any different, but there is a balance to be found.

Pensions are in some ways like any other sort of investment. Investor education is improving and people want more information about their investments - and fast. With money purchase investments, members also want more freedom of choice in investment styles and the ability to switch at no cost. All these things can be provided cheaply and quickly with the new technology.

At the same time, pensions are different from other financial products. They are usually linked to employment and offered as part of a benefits package. There is a need for disclosure of sensitive information, such as salary details or health and family situations, but members expect this data to be protected. So members expect increased access to their own information but with the expectation of total security of that information.

Data protection with its privacy and human rights aspects is a live issue and one which trustees will need to watch. Digital signatures are not in everyday use, but they soon could be and pension schemes will need to keep up to date with e-issues on a regular basis. 